\title{
The Chilling Effect of Campus Carry: How the Kansas Campus Carry Statute Impermissibly Infringes Upon the Academic Freedom of Individual Professors and Faculty Members
}

\author{
Christopher M. Wolcott*
}

I. INTRODUCTION

In recent years, the University of Kansas has experienced political unrest, ${ }^{1}$ seen the rise of social justice movements, ${ }^{2}$ felt the pain and stigma associated with campus sexual assault, ${ }^{3}$ and witnessed professors and other faculty members make controversial statements while lecturing on topics that challenge students' beliefs, force them out of their comfort-zones, and require them to re-evaluate how they view the world. ${ }^{4}$ In other words, the University of Kansas is a typical American

* J.D. Candidate 2017, University of Kansas School of Law; B.A. Government and National Security: Politics and Government 2013, Tiffin University. I would first like to thank my Note and Comment Editors, CJ Boyd and Beth Hanus, for their tireless efforts, invaluable feedback, and constant encouragement throughout the writing process. I am also grateful for the members of the Kansas Law Review and all of their help in publishing this Comment. In addition, I would like to thank Professor Tom Stacy for his helpful suggestions and advice and Dr. Gene Chintala of Tiffin University who taught me the importance of thinking critically when evaluating complex issues as well as my own beliefs. Finally, I would like to thank my wife Rebecca and the rest of my family and friends for their never-ending love, support, patience, and encouragement throughout my time in law school. Rock Chalk!

1. See Miranda Davis, Updated: Chancellor Bernadette Gray-Little and Student Body President and Vice President Discuss Race and Other Topics Amongst KU Students, U. DAILY KANSAN (Dec. 7, 2014), http://www.kansan.com/news/updated-chancellor-bernadette-gray-littleand-student-body-president-and/article_4dbfcd60-7e88-11e4-b390-f31cc5918abe.html.

2. See Lara Korte, RCIH Pushes for Change Through Advocacy and Protests, U. DAILY KANSAN (Jan. 17, 2016), http://www.kansan.com/news/rcih-pushes-for-change-through-advocacyand-protests/article_771e1eb4-bd66-11e5-90af-6f727f761cf0.html.

3. See Allison Hammond, KU Added to List of Schools Investigated for Handling of Sexual Assault Cases, U. DAILY KANSAN (July 29, 2014), http://www.kansan.com/news/ku-added-to-listof-schools-investigated-for-handling-of/article_0cc904c4-56be-5435-bfa9-6585be710f53.html; McKenna Harford, Presenters at KU School of Law Holds Symposium About How Universities Can Better Handle Sexual Assault Cases, U. DAILY KANSAN (Oct. 25, 2015), http://www.kansan.com/news/presenters-at-ku-school-of-law-holds-symposium-abouthow/article_07eb266c-7b63-11e5-a460-837b9c2d3c63.html.

4. See Lara Korte, COMS Professor Not Found in Violation of KU Policy After Investigation into Using Racial Slur in Class, U. DAILY KANSAN (Mar. 23, 2016), http://www.kansan.com/news/coms-professor-not-found-in-violation-of-ku-policy- 
university - albeit one with an exceptional basketball team - that, day in and day out, experiences all of the challenges, trials, and tribulations associated with bringing a large and diverse group of people together for the purpose of education. However, in 2012 members of the Kansas State Legislature looked at this conglomeration of ideas, personalities, cultures, and emotions and deemed it to be particularly at risk of being attacked. $^{5}$ It was therefore necessary, in the eyes of those legislators, to pass a law allowing for the concealed carry of firearms in all buildings on public college campuses within the state unless "adequate security measures" were implemented. ${ }^{6}$ That law, an amendment to the Personal and Family Protection Act, went into effect on July 1, 2013 but included a four-year grace period to allow universities to implement adequate security measures if they so chose. ${ }^{7}$ Therefore, as the law currently stands, all public universities within the state of Kansas that do not implement adequate security measures will be forced to open the buildings on their campuses to concealed carry firearms on July 1, $2017 .{ }^{8}$

The Kansas Legislature pointed toward student and faculty safety as its central justification for passing its campus carry statute. ${ }^{9}$ Advocates for the law alleged that without allowing the concealed carry of firearms - or other adequate security measures - in campus buildings, the University of Kansas, along with every other public college and university within the state, would be vulnerable to attack because the students and faculty would be unable to properly defend themselves, particularly against armed intruders. ${ }^{10}$ However this justification ignores another characteristic that the University of Kansas shares with the majority of American universities: it has never been the victim of any

after/article_26909564-f103-11e5-a024-27d56f9f2d50.html.

5. See Kansas House Approves Changes to Concealed-Carry Law, WiChita EAGLE (Mar. 12, 2012, 5:00 AM), http://www.kansas.com/news/politics-government/article1088066.html [hereinafter Kansas House] (commenting on the bill that would go on to amend the Personal and Family Protection Act and allow concealed carry on campus).

6. See Dion Lefler, Kansas Regents Prepare to Open Universities to Guns Under New Law, Wichita EAGLE (Oct. 5, 2015, 7:02 PM) (quoting Act of Apr. 16, 2013, ch. 105, § 2, 2013 Kan.
Laws
551 ,
$551-53$
(amended
2016)),

http://www.kansas.com/news/local/education/article37900224.html.

7. See KAn. StAT. AnN. § 75-7c20 (Supp. 2016); see also Lefler, supra note 6.

8. See $§ 75-7 \mathrm{c} 20$.

9. See Kansas House, supra note 5.

10. See id.; see also Scott Rothschild, Kansas Senate Advances Expansion of Concealed Carry of Guns, L.J. WORLD (March 26, 2013), http://www2.ljworld.com/news/2013/mar/26/kansas-senateadvances-expansion-concealed-carry-g/ (quoting Senator Forrest Knox as stating that: "When a gun is in a school and harm is meant, there is only one thing that is going to stop that, and that is another gun"). 
type of on-campus, mass-shooting-style attack. ${ }^{11}$ In fact, none of the public colleges or universities in the state of Kansas have ever experienced any such incident. ${ }^{12}$ Therefore, despite student and faculty safety being espoused as a central justification for campus carry in Kansas, the reality is that the campus carry statute will likely have little to no effect on the safety of faculty and students and could, arguably, even make them less safe. What the campus carry statute does do, this Comment will argue, is undoubtedly have a chilling effect on the academic freedom of individual professors to control their classroom environment, to choose the topics on which they wish to lecture, and to facilitate challenging and, at times, controversial discussions with their students. The campus carry statute therefore incidentally limits the First Amendment academic freedom rights of Kansas professors and is thereby subject to heightened scrutiny. Ultimately, this Comment will argue, the Kansas campus carry statute fails that heightened scrutiny and, as a result, should be invalidated. ${ }^{13}$

Section II.A of this Comment will look at the background of the campus carry movement, detailing its origins, its spread across the country, and some of its successes in implementing campus carry laws at the state level. The section will then provide a closer look at the Kansas campus carry statute that was passed and implemented in 2013. Section II.B will then analyze the concept of academic freedom by tracing its historical background and then providing an overview of the Supreme Court's academic freedom jurisprudence. It will then conclude by describing the circuit split between the Fourth and Seventh Circuits on the issue of individual academic freedom.

Section III.A of this Comment will address the circuit split and provide analysis that seeks to resolve that discrepancy in favor of

11. See List of School Shootings in the United States, WIKIPEDIA, https://en.wikipedia.org/wiki/List_of_school_shootings_in_the_United_States (last updated Mar. 23, 2017, 7:21 AM). The only exception to this premise occurred in 1892 when a University of Kansas law student shooting of two students who were cutting across the property on their way back to their dorm. See Two Students Shot, Morning CaLl (S.F.), Oct. 11, 1892, at 1, http://cdnc.ucr.edu/cgibin/cdnc? $\mathrm{a}=\mathrm{d} \& \mathrm{~d}=\mathrm{SFC} 18921011.2 .29$. However, that incident is irrelevant to this Comment.

12. See List of School Shootings in the United States, supra note 11.

13. This Comment will focus exclusively on how the Kansas campus carry statute implicates and affects the individual academic freedom of professors and other faculty members who work and teach at public colleges and universities in Kansas. For an in-depth look at how the statute can affect the institutional academic freedom of the colleges and universities themselves, see Laura Houser Oblinger, Note, The Wild, Wild West of Higher Education: Keeping the Campus Carry Decision in the University's Holster, 53 WASHBURN L.J. 87 (2013). Similarly, while additional First Amendment challenges could be made to the Kansas campus carry statute-such as application of Pickering balancing or the public forum doctrine - those are also outside of the purview of this Comment. 
individual academic freedom. Section III.B will then discuss the various levels of scrutiny that could be applied to the Kansas campus carry statute and will ultimately argue that intermediate scrutiny should apply. Finally, Section III.C will apply intermediate scrutiny to the Kansas campus carry statute and will argue that, under the heightened standard, the law must fail.

\section{BACKGROUND}

This part begins by providing details about the origins of the campus carry movement. It then provides a brief overview of the current statutory landscape in the United States and outlines the Kansas campus carry statute. This part also describes the doctrine of academic freedom by tracing the doctrine's historical roots in both the German universities and the American professional organizations. It then outlines the Supreme Court's jurisprudence regarding academic freedom before closing with a description of the circuit split that has developed between the Fourth and Seventh Circuits regarding individual academic freedom.

\section{A. The Campus Carry Movement}

1. Origins and Current Campus Carry Statutes

The morning of April 16, 2007, a gunman, later identified as Cho Seung-Hui, carried out the deadliest mass shooting on a college campus in American history when he shot and killed thirty-two students and injured seventeen more at Virginia Tech University before turning the gun on himself and committing suicide. ${ }^{14}$ The next morning, before the shock of the Virginia Tech massacre had even begun to wear off, a number of students from states across the country came together to form Students for Concealed Carry on Campus. ${ }^{15}$ The organization's goal was to even the playing field by eliminating state laws and "school policies that prohibit concealed carry on college campuses [and thereby] stack the odds in favor of dangerous criminals who have no concern for following the rules."16 Over the next year, Students for Concealed Carry on

14. Christine Hauser \& Anahad O’Connor, Virginia Tech Shooting Leaves 33 Dead, N.Y. TIMES (Apr. 16, 2007), http://www.nytimes.com/2007/04/16/us/16cnd-shooting.html; Christine Hauser, Virginia Gunman Identified as a Student, N.Y. Times (Apr. 17, 2007), http://www.nytimes.com/2007/04/17/us/17virginia.html.

15. Adam Weinstein, The Secret History of the Campus Carry Movement, TRACE (July 5, 2015), https://www.thetrace.org/2015/07/the-making-of-the-campus-carry-movement/.

16. See Interview by Suzanne Smalley with W. Scott Lewis, Bd. Member, Students for 
Campus would begin to spread to campuses across the country with a network of student activists devoted to the cause. ${ }^{17}$

Since its inception in 2007, Students for Concealed Carry, as it has come to be called, has experienced remarkable growth and now boasts over 43,000 members on more than 350 campuses nationwide. ${ }^{18}$ This growth is largely due to the influence and support of conservative leaders including Morton C. Blackwell, founder of the Leadership Institute, as well as Larry Pratt, leader of Gun Owners of America. ${ }^{19}$ Surprisingly, the National Rifle Association has largely stayed away from the campus carry issue, preferring to pursue higher priority causes and leaving campus carry to the "gundamentalists" or "purists" 20 who believe that all restrictions on gun rights are in violation of the Second Amendment to the United States Constitution. ${ }^{21}$ As a result, Students for Concealed Carry, like the campus carry movement in general, has been able to maintain its grassroots identity while quickly, and relatively quietly, spreading all around the country. ${ }^{22}$

Despite the widespread nature of the movement and its ability to recruit young and motivated student leaders, campus carry has enjoyed only limited success when it comes to the actual passage of legislation allowing for concealed carry on campus. ${ }^{23}$ In the first half of 2015, fifteen different states took up the issue, but only Texas was able to successfully enact a campus carry statute, albeit an extremely waterdowned version of one. ${ }^{24}$ In fact, Nathan Deal-the Republican

Concealed Carry on Campus (Feb. 14, 2008), quoted in Suzanne Smalley, More Guns on Campus?, NewSWEEK (Feb. 14, 2008, 7:00 PM), http://www.newsweek.com/more-guns-campus-94233.

17. Weinstein, supra note 15.

18. Id.

19. Id.

20. Id. (quoting an unnamed, former NRA lobbyist).

21. See James E. Atwood, Gundamentalism and Where It Is Taking America 46-48 (2017).

22. See Weinstein, supra note 15.

23. Michael S. Rosenwald, Guns Go to College: Everything You Need to Know About Campus Carry, WASH. POST (July 31, 2016), https://www.washingtonpost.com/news/local/wp/2016/07/30/everything-you-need-to-know-aboutcampus-carry/.

24. Weinstein, supra note 15. A trio of college professors from the University of Texas at Austin, are currently challenging the Texas campus carry statute in the United States District Court for the Western District of Texas. See Complaint, Glass v. Paxton, No. 1:16-cv-845 (W.D. Tex. July 6,2016 ). While the lawsuit is still in its infancy (the Complaint was filed on July 6, 2016), the plaintiffs have already advanced arguments alleging that the statute infringes upon their individual academic freedom rights under the First Amendment and has done so without a compelling justification. See id. at 10,13,15. However, it should be noted that the Texas campus carry statute differs from the Kansas campus carry statute in a number of important respects. First, in Texas people who carry concealed firearms must have a permit to do so whereas in Kansas, a constitutional 
Governor of Georgia who has been given an "A" rating by the National Rifle Association-vetoed Georgia's campus carry bill, noting "that 'colleges have been treated as sanctuaries of learning where firearms have not been allowed" and that "he saw no justification to change that." 25 Therefore, when Kansas' campus carry statute is implemented on July $1,2017,{ }^{26}$ it will be one of just a handful of states throughout the country that have similar statutes allowing concealed carry on campus. ${ }^{27}$ However, even with such limited success, the campus carry movement has become like an evangelical crusade for young gun-rights activists, many of whom are committed to making a name for themselves within the grassroots campaign with hopes of using their successes to quickly climb through the ranks of the Republican party. ${ }^{28}$

Currently, ten states have statutes allowing concealed carry on their public college and university campuses. ${ }^{29}$ Each of these ten, including Kansas, has provisions allowing for anyone-including students, faculty, administrators, staff, and even visitors - to concealed carry weapons on campus. "These states are Arkansas, Colorado, Georgia, Idaho, Kansas, Mississippi, Oregon, Texas, Utah and Wisconsin."31 In addition,

carry state, no such permit is required. Compare TeX. Gov'T CODE ANN. § 411.2031(b) (West, Westlaw through the end of the 2015 Reg. Sess. Of the $84^{\text {th }}$ Leg.), with KAN. STAT. ANN. $§ 75-7 c 20$ (Supp. 2016). Second, the Texas statute makes no mention of "adequate security measures" and instead allows for the concealed carry of firearms in all public university buildings regardless of their features. Compare TEX. GOV'T CODE ANN. § 411.2031 (West, Westlaw through the end of the 2015 Reg. Sess. Of the $84^{\text {th }}$ Leg.) with Kan. Stat. AnN. $§ 75-7$ c20 (Supp. 2016). Finally, the Texas statute does not strip public universities of all power and instead allows them to promulgate reasonable rules and regulations for the concealed carry of firearms on their campuses so long as those rules and regulations do not "generally prohibit or have the effect of generally prohibiting" the concealed carry of firearms on campus. TEX. Gov'T CODE ANN. $§ 411.2031$ (d)-(e) (West, Westlaw through the end of the 2015 Reg. Sess. Of the $84^{\text {th }}$ Leg.).

25. Rosenwald, supra note 23 (quoting NATHAN DeAL, 2016 Session of THE Georgia GeNeral ASSEMBly: GeNeral Legislation-Veto Messages (2016)).

26. See discussion infra Section II.A.2.

27. See Guns on Campus' Laws for Public Colleges and Universities, ARMED CAMPUSES, http://www.armedcampuses.org (last visited Feb. 28, 2017). In addition to Kansas, Mississippi, Arkansas, Wisconsin, and Oregon allow concealed carry on campus but enable campus administrators to limit where concealed carry may be prohibited (e.g. through the implementation of adequate security measures) as well as, in some cases, who may and may not possess concealed carry weapons on campus. See id. Meanwhile, Texas, Colorado, Utah, Idaho, and Tennessee allow concealed carry anywhere on campus, subject to some state-specific restrictions. See id. Information on these states' restrictions on campus carry can be found by clicking on the states in the map on Armed Campuses' main page. See id.

28. See Weinstein, supra note 15.

29. See Guns on Campus: Overview, Nat'L Conf. St. Legislatures (May 5, 2017), http://www.ncsl.org/research/education/guns-on-campus-overview.aspx.

30. See id. Each state statute varies slightly, with some including specific exceptions and/or qualifiers, but those variations are not pertinent to this Comment.

31. Id. 
Tennessee allows certain faculty members to carry weapons on campus but its "law does not extend to students or the general public." 32 This leaves sixteen states ${ }^{33}$ that ban the concealed carry of a weapon on college campuses completely ${ }^{34}$ and twenty-three states ${ }^{35}$ that leave the decision whether to ban concealed carry on campus to each individual college and university. ${ }^{36}$

\section{Kansas Campus Carry Statute}

The debate over allowing the concealed carry of weapons on college campuses came to Kansas in 2013 when state lawmakers proposed a bill modifying the Personal and Family Protection Act. ${ }^{37}$ The proposed legislation sought to require the installation of adequate security measures at public entrances of state and municipal buildings (including all buildings on the campuses of public colleges and universities) to prevent weapons from being carried into those buildings. ${ }^{38}$ These adequate security measures were defined as:

[T] he use of electronic equipment and personnel at public entrances to detect and restrict the carrying of any weapons into the state or municipal building, including, but not limited to, metal detectors, metal detector wands or any other equipment used for similar purposes to ensure that weapons are not permitted to be carried into such building by members of the public.

The bill went on to propose language that allowed for the possession of firearms in any state or municipal building ${ }^{40}$ that did not have adequate security measures so long as those firearms were concealed carried within those buildings. ${ }^{41}$ Finally, the proposed bill gave the governing

\footnotetext{
32. See id.

33. "California, Florida, Illinois, Louisiana, Massachusetts, Michigan, Missouri, Nebraska, Nevada, New Jersey, New Mexico, New York, North Carolina, North Dakota, South Carolina and Wyoming." Id.

34. Id.

35. “Alabama, Alaska, Arizona, Connecticut, Delaware, Hawaii, Indiana, Iowa, Kentucky, Maine, Maryland, Minnesota, Montana, New Hampshire, Ohio, Oklahoma, Pennsylvania, Rhode Island, South Dakota, Vermont, Virginia, Washington and West Virginia." Id.

36. Id.

37. See S. Substitute for H.R. 2052, 2013 Leg., Reg. Sess. (Kan. 2013).

38. S. Substitute for H.R. 2052, 85th Leg., Reg. Sess. (Ks. 2013).

39. S. Substitute for H.R. 2052, 85th Leg., Reg. Sess. (Ks. 2013).

40. However, despite purportedly being enacted to ensure public safety, the statute that was ultimately passed specifically exempted the state capitol building from its definition of "state and municipal building.” See Kan. STAT. ANN. § 75-7c20(m)(7)(B) (Supp. 2016).

41. S. Substitute for H.R. 2052, 85th Leg., Reg. Sess. (Ks. 2013).
} 
body or administrator of all state or municipal buildings a four-year exemption to establish the "adequate security measures" necessary to prevent weapons from entering the building. ${ }^{42}$

The proposed bill enjoyed widespread support in the Kansas legislature and was passed on April 5, 2013, by a vote of thirty-two to seven in the Kansas Senate and a vote of 104 to sixteen in the Kansas House of Representatives. ${ }^{43}$ Governor Sam Brownback signed it into law on April 16, 2013. ${ }^{44}$ Ultimately, the pertinent language of the enacted statute stated:

(a) The carrying of a concealed handgun shall not be prohibited in any public area of any state or municipal building unless such public area has adequate security measures to ensure that no weapons are permitted to be carried into such public area and the public area is conspicuously posted with either permanent or temporary signage approved by the governing body, or the chief administrative officer, if no governing body exists, in accordance with K.S.A. 75-7c10, and amendments thereto.

(b) The carrying of a concealed handgun shall not be prohibited throughout any state or municipal building in its entirety unless such building has adequate security measures at all public access entrances to ensure that no weapons are permitted to be carried into such building and the building is conspicuously posted in accordance with K.S.A. 75$7 \mathrm{c} 10$, and amendments thereto.

Given that the statute was enacted on July 1, 2013, governing bodies and administrators of state and municipal buildings, including those in charge of Kansas' public colleges and universities, were given until July 1, 2017 to determine what they were going to do to comply with the law: either install adequate security measures or allow the concealed carry of weapons on campus. ${ }^{46}$

Contrary to its widespread support in the Kansas Legislature, the campus carry statute has faced harsh criticism from university administrators, faculty, and students. ${ }^{47}$ Many fear that allowing

42. S. Substitute for H.R. 2052, 85th Leg., Reg. Sess. (Ks. 2013).

43. S. Substitute for H.R. 2052, 85th Leg., Reg. Sess. (Ks. 2013).

44. S. Substitute for H.R. 2052, 85th Leg., Reg. Sess. (Ks. 2013).

45. Kan. STAT. AnN. $§ 75-7 c 20(a)-(b)$ (Supp. 2016).

46. See id. $\S 75-7 \mathrm{c} 20(\mathrm{j})$.

47. See GARy Brinker \& RyAn L. SWAyne, KANSAS BOARD OF Regents Student Advisory COMMITTEe StUdent Gun Policy OPINION Survey 2-6 (2015), http:/www.fhsustudents.org/wp-content/uploads/2016/01/Regents-Student-Gun-Survey-2015.pdf; Sam Zeff, Kansas Campuses Prepare for Guns in Classrooms, NPR (Mar. 22, 2016, 7:00 AM), http:/www.npr.org/sections/ed/2016/03/22/470717996/kansas-campuses-prepare-for-guns-in- 
concealed weapons to be carried on campus and in classrooms will result in accidents and escalated disagreements between students. ${ }^{48}$ In addition, some worry that the "fear of violence could discourage civil discourse, with students afraid to speak their minds 'because of their worry that someone might react with armed violence instead of thoughtful debate." "49 To quantify this reaction, a survey was sent out to administrators, faculty, and employees at all of the Kansas Board of Regents colleges and universities. ${ }^{50}$ Out of the more than 20,000 responses, 82 percent stated that allowing students to carry guns to class made them feel less safe. ${ }^{51}$ Additionally, 70 percent stated that allowing campus carry "would negatively impact their course and how they teach," almost half said that they believed campus carry "would increase crime on campus," and a full two-thirds of all respondents stated that campus carry "would limit their freedom to teach ... and engage with students in a way that optimizes learning." 52 However, despite the strong opposition to the measure, the Kansas Legislature has rebuffed all efforts to change or repeal the legislation. Given the prohibitively high cost associated with installing adequate security measures in all campus buildings, ${ }^{53}$ campus administrators, faculty, and students are beginning to resign themselves to the fact that campus carry will become a reality on July $1,2017$.

\section{B. Individual Academic Freedom}

\section{Origins}

\section{a. The German Influence}

Unlike the campus carry movement, which is a relatively recent phenomenon, the concept of academic freedom has been wrapped up in higher education for centuries. However, despite this long history, it has remained a concept that is notorious for being "ill-defined" and "poorly understood." $"$ That is not to say, however, that nobody has ever tried.

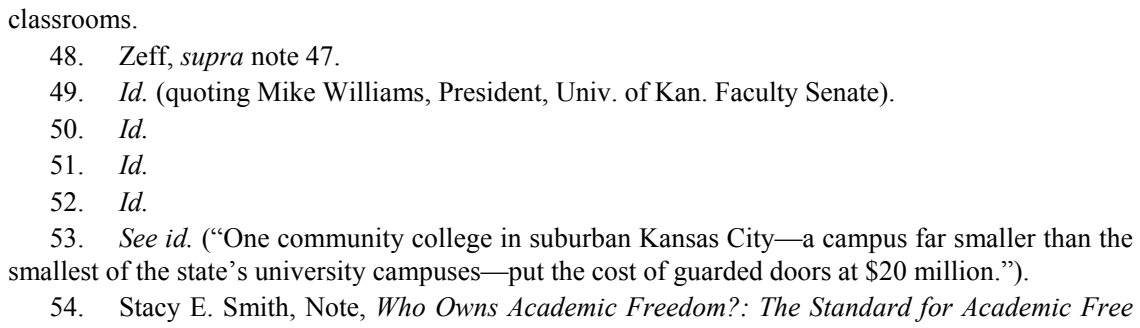


In the late nineteenth century, the Germans embraced a definition of academic freedom that focused on "three interrelated principles: Lehrfreiheit, Lernfreiheit, and Freiheit der Wissenschaft." "55 The first of these principles, Lehrfreiheit, meant "teaching freedom" and "it referred to the statutory right of full and associate professors ... to discharge their professional duties outside the chain of command that encompassed other government officials." ${ }^{, 56}$ This, in turn, allowed university professors to control the "content of their lectures and to publish the findings of their research without seeking prior ... approval" or fearing retribution by the state or church. ${ }^{57}$ In essence Lehrfreiheit "protected the restiveness of academic intellect" exploration, and spreading of new ideas-"from the obedience norms of hierarchy." 59

The second principle, Lernfreiheit, meant "learning freedom" and "it amounted to a disclaimer by the university of any control over the students' course of study save that which they needed to prepare them for state professional examinations or to qualify them for an academic teaching license." 60 This principle granted students the right to determine for themselves what they wanted to study and, in doing so, emphasized the German view that the university should serve "primarily as a purveyor of knowledge and as a credentializing agency, not as a parent surrogate or landlord." 61 This freedom was considered a "reward for achievement" and was cherished by students as a "precious privilege" that they utilized to conform their education to a style that best met their academic needs. ${ }^{62}$

Finally, the third principle, Freiheit der Wissenschaft stood for the concept of "[a]cademic self-government"; a concept that essentially defined the right of the university to handle its own affairs, generally

Speech at Public Universities, 59 WASH. \& LEE L. REV. 299, 307 (2002) (quoting Michael A. Olivas, Reflections on Professional Academic Freedom: Second Thoughts on the Third "Essential Freedom”, 45 STAN. L. REV. 1835, 1835 (1993)).

55. Walter P. Metzger, Profession and Constitution: Two Definitions of Academic Freedom in America, 66 TEX. L. REV. 1265, 1269 (1988).

56. Id.

57. $I d$.

58. Id.

59. Id.

60. Id. at 1270 .

61. See id.

62. See Larry D. Spurgeon, A Transcendent Value: The Quest to Safeguard Academic Freedom, 34 J.C. \& U.L. 111, 118-19 (2007) (quoting RichARD HOFSTADTER \& WALTER P. MetZGer, The DeVelopment of ACAdEMic FreEdom In the United StATES 387 (1955), for the term "precious privilege"). 
"under the direction of its senior professors organized into separate faculties and a common senate." 63 This principle is inextricably intertwined with the first two, Lehrfreiheit (freedom to teach) and Lernfreiheit (freedom to learn), because without broad institutional powers of their own, universities and the world of academia "would be at the mercy of the state or church" and "dangerously vulnerable to government or religious censorship."64 As a result, defining and incorporating this institutional level academic freedom was deemed vital to protecting the individual academic freedoms enjoyed by German teachers and students. ${ }^{65}$

\section{b. Academic Freedom Comes to the United States}

i. The Professional Standards

The American concept of academic freedom evolved out of the German tradition and emerged at the turn of the nineteenth century as "many American college graduates migrated to German universities for advanced instruction and returned persuaded that the Germans' concept of academic freedom should be mirrored in the United States." ${ }^{\text {"66 }}$ In response, the American Association of University Professors ("AAUP") issued its General Report of the Committee on Academic Freedom and Academic Tenure, ${ }^{67}$ commonly known as the "1915 Declaration of Principles," $" 68$ in which it provided, for the first time, an American conception of academic freedom. ${ }^{69}$ This declaration "defined academic freedom as comprising... three elements: 'freedom of inquiry and research; freedom of teaching within the university or college; and freedom of extramural utterance and action.",70 However, despite the 1915 Declaration's clearly being inspired by the Germans, it also represented a significant departure from the German tradition in that its sole focus was on protecting the academic freedom of individual

\footnotetext{
63. Metzger, supra note 55, at 1270.

64. See id.

65. See id. at $1270-71$.

66. Smith, supra note 54, at 309.

67. Comm. on Acad. Freedom \& Acad. Tenure, Am. Ass'n of Univ. Professors, General Report of the Committee on Academic Freedom and Academic Tenure, 1 Bull. AM. Ass'N U. PROFESSORS 15 (1915), http://www.jstor.org/stable/40216731.

68. See Walter P. Metzger, The 1940 Statement of Principles on Academic Freedom and Tenure, LAW \& CONTEMP. PROBS., Summer 1990, at 3, 13 n.13.

69. See Metzger, supra note 55, at 1267.

70. Smith, supra note 54, at 310 (quoting Comm. on Acad. Freedom \& Acad. Tenure, Am. Ass'n of Univ. Professors, supra note 67, at 20).
} 
professors and not that of the students or of the universities as institutions. $^{71}$ And while it was a significant step forward for American universities, it was largely a symbolic one as the 1915 Declaration lacked legal-enforcement mechanisms. ${ }^{72}$

A number of years later, the AAUP joined forces with the Association of American Colleges ("AAC") and attempted to "condense and revise" the 1915 Declaration. ${ }^{73}$ This resulted in a document entitled Academic Freedom and Tenure: Statement of Principles, $1940^{74}$ that, "[a]t its heart... endorsed the same core principles as the 1915 Declaration."75 On top of these core principles, the 1940 statement established three substantive rules:

(a) The teacher is entitled to full freedom in research and in the publication of the results, subject to the adequate performance of his other academic duties; but research for pecuniary return should be based upon an understanding with the authorities of the institution.

(b) The teacher is entitled to freedom in the classroom in discussing his subject, but he should be careful not to introduce into his teaching controversial matter which has no relation to his subject. Limitations of academic freedom because of religious or other aims of the institution should be clearly stated in writing at the time of the appointment.

(c) The college or university teacher is a citizen, a member of a learned profession, and an officer of an educational institution. When he speaks or writes as a citizen, he should be free from institutional censorship or discipline, but his special position in the community imposes special obligations. As a man of learning and an educational officer, he should remember that the public may judge his profession and his institution by his utterances. Hence he should at all times be accurate, should exercise appropriate restraint, should show respect for

71. See id. at 310-11 (characterizing the 1915 Declaration as "adapting the German concept of academic freedom to the American context" in its focus on professors and not students or institutions); Spurgeon, supra note 62, at 123-24, 124 n.90 (explaining that the 1915 Declaration "acknowledged the German tradition" but was not concerned with the academic freedom of students or of institutions); see also Comm. on Acad. Freedom \& Acad. Tenure, Am. Ass'n of Univ. Professors, supra note 67, at 20 ("[T] he freedom which is the subject of this report is that of the teacher.").

72. Spurgeon, supra note 62 , at 128.

73. See Bridget R. Nugent \& Julee T. Flood, Rescuing Academic Freedom from Garcetti v. Ceballos: An Evaluation of Current Case Law and a Proposal for the Protection of Core Academic, Administrative, and Advisory Speech, 40 J.C. \& U.L. 115, 129 (2014).

74. Ass'n of Am. Colls. \& Am. Ass'n of Univ. Professors, Academic Freedom and Tenure: Statement of Principles, 1940, 27 BULL. AM. Ass'N U. ProfESSORS 40 (1941) [hereinafter Statement of Principles, 1940], http://www.jstor.org/stable/40219177.

75. See Nugent \& Flood, supra note 73 , at 129. 
the opinions of others, and should make every effort to indicate that he is not an institutional spokesman. ${ }^{76}$

Each of these rules highlighted a specific academic freedom and helped the 1940 statement become the "most influential expression of academic freedom principles" in American history. ${ }^{77}$ Since its publication, the 1940 statement has been endorsed by "over 200 learned societies and higher education associations" and has even been incorporated into the faculty contracts at hundreds of institutions of higher learning. ${ }^{78}$ As a result, the 1940 statement has had a significant impact on higher education over the past seventy-five years. However, despite its endorsement by higher education and incorporation into faculty contracts, the 1940 statement, like the 1915 Declaration, is what is called "soft law," meaning that universities must incorporate it into their official policies for it to have any type of legal effect. ${ }^{79}$

\section{ii. The Supreme Court}

In what can be seen as a "Golden Age of Academic Freedom," the 1950s through the 1960s, the Supreme Court began playing with the idea that the concept of academic freedom should be more than just a professional organization standard and should have some legal force in the United States. ${ }^{80}$ Like anything with the Supreme Court, however, this process began slowly and evolved gradually over time. Lawrence White, Vice President and General Counsel at the University of Delaware, has written an excellent overview of the landmark Supreme Court cases regarding academic freedom and, in doing so, noted that the first Supreme Court case to mention academic freedom was Adler $v$.

\footnotetext{
76. Statement of Principles, 1940, supra note 74, at 41.

77. See Lawrence White, Fifty Years of Academic Freedom Jurisprudence, 36 J.C. \& U.L. 791, 802-03 (2010).

78. Nugent \& Flood, supra note 73, at 129.

79. Smith, supra note 54, at 312-13 (quoting William W. Van Alstyne, Academic Freedom and the First Amendment in the Supreme Court of the United States: An Unhurried Historical Review, L. \& CONTEMP. PRoBs. 79, Summer 1990, at 79, 80). Specifically at the University of Kansas, the 1940 statement has been incorporated into the Handbook for Faculty and Other Unclassified Staff. See UnIV. OF KAN., HANDBOOK FOR FACULTY AND OTHER UNCLASSIFIED STAFF 30 (2010), http://policy.ku.edu/sites/policy.ku.edu/files/FacultyandUnclassifiedStaffHandbook_20170119_0.pd f.

80. See generally Smith, supra note 54; Richard H. Hiers, Institutional Academic Freedom vs. Faculty Academic Freedom in Public Colleges and Universities: A Dubious Dichotomy, 29 J.C. \& U.L. 35, 43-57 (2002).
} 
Board of Education, ${ }^{81}$ decided in $1952 .{ }^{82}$ In Adler, the plaintiffs brought an action seeking a declaratory judgment that the New York Civil Service law allowing civil service organizations to disqualify job applicants who were members of groups that advocated for the forceful overthrow of the government was unconstitutional. ${ }^{83}$ However, the majority of the Court came down against the plaintiffs and upheld the law. ${ }^{84}$ Justice Douglas, with Justice Black concurring, wrote a dissenting opinion in which he eviscerated the majority, opining that "[w]hat happens under this law is typical of what happens in a police state." ${ }^{.85}$ Justice Douglas went on to conclude that "[t]here can be no real academic freedom in that environment." 86

It would be another five years after this initial mention by the Court for academic freedom to be seriously mentioned again; this time in a plurality and also, more significantly, in a concurrence. ${ }^{87}$ In Sweezy $v$. New Hampshire ${ }^{88}$ the defendant was convicted of contempt for refusing to answer questions posed by the State Attorney General as part of an investigation into subversive activities. ${ }^{89}$ A plurality of the Court overturned the defendant's contempt conviction and held that such a conviction violated the defendant's rights to "academic freedom and political expression." 90 In support of this holding, Chief Justice Warren, writing for the plurality, attempted to define what was meant by academic freedom, stating:

The essentiality of freedom in the community of American universities is almost self-evident. No one should underestimate the vital role in a democracy that is played by those who guide and train our youth. To impose any strait jacket upon the intellectual leaders in our colleges and universities would imperil the future of our Nation. No field of education is so thoroughly comprehended by man that new discoveries cannot yet be made. Particularly is that true in the social sciences, where few, if any, principles are accepted as absolutes. Scholarship cannot flourish in an atmosphere of suspicion and distrust. Teachers and students must always remain free to inquire, to study and

\footnotetext{
81. Adler v. Bd. of Educ., 342 U.S. 485 (1952), abrogated by Keyishian v. Bd. of Regents of the Univ. of N.Y., 385 U.S. 589 (1967).

82. White, supra note 77 , at 804.

83. Adler, 342 U.S. at $486-90,487$ n.3.

84. Id. at 496.

85. Id. at 510 (Douglas, J., dissenting).

86. Id.

87. See White, supra note 77 , at $807-10$.

88. 354 U.S. 234 (1957) (plurality opinion).

89. Id. at $236-45$

90. Id. at $250,254-55$.
} 
to evaluate, to gain new maturity and understanding; otherwise our civilization will stagnate and die.

This relatively "stunted embrace" of the concept of academic freedom by Chief Justice Warren would not, by itself, have been very influential. ${ }^{92}$ However, when combined with Justice Frankfurter's concurring opinion, Sweezy v. New Hampshire became the bedrock for academic freedom jurisprudence in the United States. ${ }^{93}$

In his concurring opinion, Justice Frankfurter laid out his four essential freedoms of a university, stating:

"It is the business of a university to provide that atmosphere which is most conducive to speculation, experiment and creation. It is an atmosphere in which there prevail 'the four essential freedoms' of a university - to determine for itself on academic grounds who may teach, what may be taught, how it shall be taught, and who may be admitted to study." ${ }^{94}$

Justice Frankfurter's concurrence represents the first expansion of the concept of academic freedom since it was brought to the United States at the turn of the nineteenth century. ${ }^{95}$ It "'broke important, new conceptual ground' by characterizing academic freedom not simply as a set of rights possessed by faculty members but as essential freedoms belonging to the university as an institutional whole." 96 This remains the most extensive explanation of academic freedom that the Supreme Court has ever given, and it therefore serves as the analytical starting point for all issues involving the doctrine. ${ }^{97}$

Finally, in the 1967 case of Keyishian v. Board of Regents of the

\footnotetext{
91. Id. at 250; see also White, supra note 77, at 808 (quoting Sweezy, 354 U.S. at 250).

92. See White, supra note 77 , at 808 .

93. See id. at $808-10$.

94. Sweezy, 354 U.S. at 263 (Frankfurter, J., concurring) (quoting CONFERENCE OF REPRESENTATIVES OF THE UNIV. OF CAPE TOWN \& THE UNIV. OF THE WITWATERSRAND, THE OPEN UNIVERSITIES IN SOUTH AFRICA 10-12 (1957) [hereinafter OPEN UNIVERSITIES] (quoting Dr. T. B. Davies' address to new students in Cape Town sometime in Feb. 1953)); see also White, supra note 77, at 808-10 (emphasis omitted) (quoting Sweezy, 354 U.S. at 263 (Frankfurter, J., concurring) (quoting OPEN UNIVERSITIES, supra, at 10-12 (quoting Dr. T. B. Davies' address to new students in Cape Town sometime in Feb. 1953))) (discussing the importance of Justice Frankfurter's concurrence). See generally Hiers, supra note 80, at 43-57 (discussing Justice Frankfurter's concurrence and his use of the South African material).

95. See White, supra note 77 , at 809.

96. Id. (footnote omitted) (quoting Judith Areen, Government as Educator: A New Understanding of First Amendment Protection of Academic Freedom and Governance, 97 GEO. L.J. 945, 971 (2009)).

97. Id. at 810
} 
University of New York, ${ }^{98}$ the Supreme Court acknowledged the concept of academic freedom in a majority holding. ${ }^{99}$ The plaintiffs in the case were university professors in the State of New York who alleged that the State's policy for retention and appointment of professors was unconstitutional because it prevented professors who were members of "subversive" groups from obtaining or keeping employment at state universities. ${ }^{100}$ This case was factually very similar to Adler v. Board of Education but unlike in Adler, the Court here ruled in favor of the plaintiffs and held that the laws and regulations that denied employment at a public university solely because the person was a member of a "subversive" group violated the Constitution. ${ }^{101}$ In reaching this conclusion, the Court explained:

Our Nation is deeply committed to safeguarding academic freedom, which is of transcendent value to all of us and not merely to the teachers concerned. That freedom is therefore a special concern of the First Amendment, which does not tolerate laws that cast a pall of orthodoxy over the classroom. ${ }^{102}$

However, while Keyishian leaves the distinct impression that academic freedom is a valid right, supported by the Constitution, the Supreme Court has yet to clarify its definition or scope or how the doctrine is of special concern to the First Amendment. ${ }^{103}$

2. Development of the Distinction between Individual and Institutional Academic Freedom and the Resulting Circuit Split

While the Supreme Court's decisions in the 1950s and 1960s made great strides in establishing and strengthening the American conception of academic freedom, they also left the doctrine vague and ambiguous,

\footnotetext{
98. 385 U.S. 589 (1967).

99. White, supra note 77 , at 810.

100. Keyishian, 385 U.S. at 591-92 (quoting N.Y. EdUC. LAW $\$ 3022$ (McKinney 2009) (repealed 1958)).

101. See id. at $607-10$.

102. Id. at 603; see also J. Peter Byrne, Academic Freedom: A "Special Concern of the First Amendment”, 99 YALE L.J. 251, 296-98 (1989) (quoting Keyishian, 385 U.S. at 603) (making several observations about the quoted passage from Keyishian); Hiers, supra note 80, at 42-43 (quoting Keyishian, 385 U.S. at 603) (discussing the quoted passage from Keyishian and explaining its importance); White, supra note 77, at 810-12 (emphasis omitted) (quoting Keyishian, 385 U.S. at 603) (discussing the place of the quoted passage from Keyishian in the context of academic freedom).

103. See Byrne, supra note 102, at 296-98.
} 
creating many more questions than answers. ${ }^{104}$ Over the next several decades, lower courts, relying heavily on Justice Frankfurter's concurring opinion in Sweezy, started to distinguish between institutional academic freedom and individual academic freedom. ${ }^{105}$ Richard Hiers, Professor at the University of Florida School of Law, wrote a detailed overview of this trend beginning with the case of Cooper v. Ross. ${ }^{106}$ Cooper arose in the Eastern District of Arkansas and provided the first hints of a distinction between individual and institutional academic freedom. ${ }^{107}$ The case involved the termination of Cooper from his employment at the University of Arkansas at Little Rock. ${ }^{108}$ Cooper had been a non-tenured professor of history at the University and was also a member of the Progressive Labor Party, a communist organization active within the United States. ${ }^{109}$ As an avowed communist, Cooper taught his courses from a distinctly Marxist point of view and regularly incorporated his own beliefs into his lectures. ${ }^{110}$ University officials asked Cooper whether he would comply with a command to stop if the University issued such an order, but Cooper stated that he would refuse because doing so would be intellectually dishonest. ${ }^{111}$ As a result, the University terminated Cooper's employment, a move that the court concluded was substantially motivated by Cooper's communist ties. ${ }^{112}$ While the Arkansas district court ruled in favor of Cooper in his wrongful termination suit, it also noted that the case was "particularly difficult because it involve[d] a fundamental tension between the academic freedom of the individual teacher... and the academic freedom of the university." time, a distinction between individual and institutional academic freedom, the court in Cooper failed to resolve the issue and, instead, decided the case on other grounds. ${ }^{114}$ Other courts would eventually

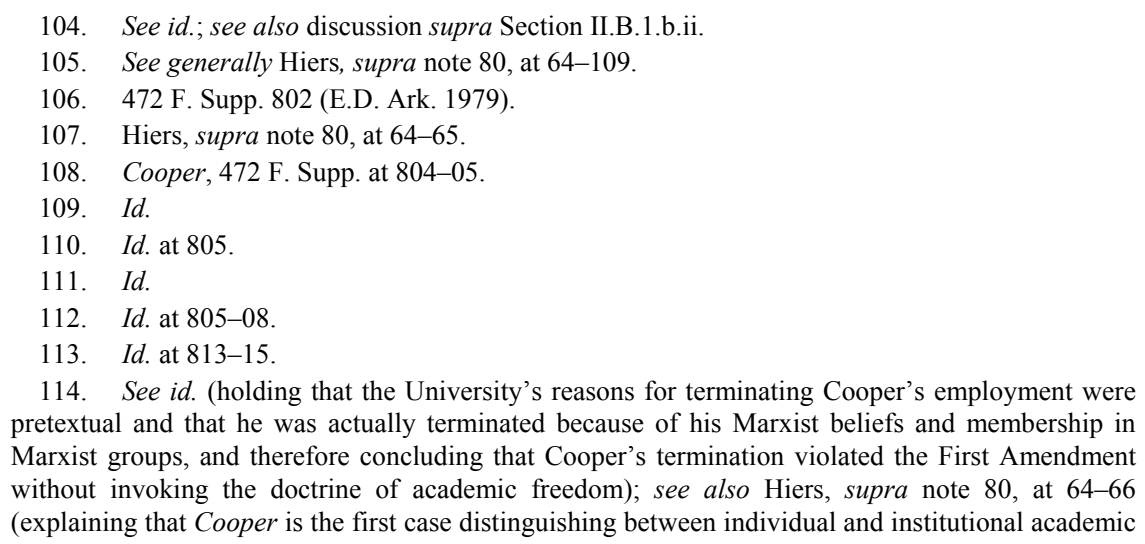

114. See id. (holding that the University's reasons for terminating Cooper's employment were pretextual and that he was actually terminated because of his Marxist beliefs and membership in Marxist groups, and therefore concluding that Cooper's termination violated the First Amendment without invoking the doctrine of academic freedom); see also Hiers, supra note 80, at 64-66 (explaining that Cooper is the first case distinguishing between individual and institutional academic 
seize on the distinction from Cooper and continue to develop the concept into the modern distinction that exists today.

\section{a. The Seventh Circuit: Piarowski v. Illinois Community College District 515}

This development began in the Court of Appeals for the Seventh Circuit, where a number of decisions delved into "the idea that a university's academic freedom might be divided or divorced from that of its faculty." 115 Like with the Supreme Court's development of the overarching academic freedom doctrine, this idea began slowly and, with a few exceptions, has remained relatively ambiguous and unclear. ${ }^{116}$ However, a significant early step in this process was the establishment of what became known as the "Piarowski Doctrine" by the Seventh Circuit. ${ }^{117}$ The doctrine arose out of Piarowski v. Illinois Community College District $515{ }^{118}$ a case in which the Seventh Circuit upheld a university's decision to move sexually explicit and racially offensive artwork, which was produced by a faculty member, out of a public and heavily trafficked thoroughfare. ${ }^{119}$ Writing for the court, Judge Posner noted that the term academic freedom is "equivocal" because "[i]t is used to denote both the freedom of the [institution] ... and the freedom of the individual teacher... and these two freedoms are in conflict." " 20 However, as with other academic freedom cases, Judge Posner made no attempt to "resolve the purported conflict between the 'two freedoms." ",121

The Supreme Court has lent some credence to Judge Posner's formulation of academic freedom, albeit in a footnote that is best described as dicta. ${ }^{122}$ Ten days after denying certiorari to the Piarowski

\footnotetext{
freedom and that the court's discussion of academic freedom is dicta because its decision did not depend on law pertaining to academic freedom).

115. Hiers, supra note 80 , at 67.

116. See Neal H. Hutchens, A Confused Concern of the First Amendment: The Uncertain Status of Constitutional Protection for Individual Academic Freedom, 39 J.C. \& U.L. 145, 154 (2009).

117. Id. at 78 .

118. 759 F.2d 625 (7th Cir. 1985).

119. Id. at $632-33$.

120. Id. at 629 (citations omitted); see also Hiers, supra note 80, at 78-81 (quoting Piarowski, 759 F.2d at 629) (explaining that the Piarowski decision "included language to the effect that academic freedom is an 'equivocal' term because it refers both to institutional academic freedom and individual academic freedom, and that these two freedoms conflict with each other" and criticizing the opinion's characterization of academic freedom as "equivocal" (quoting Piarowski, 759 F.2d at 629)).

121. Hiers, supra note 80, at 81 (quoting Piarowski, 759 F.2d at 629).

122. See id. at 81-82.
} 
case, the Supreme Court handed down its decision in Regents of the University of Michigan v. Ewing ${ }^{123}$ regarding due process in the university setting. ${ }^{124}$ There, Justice Stevens, writing for a unanimous court, upheld the dismissal of a medical student after he failed a required examination. ${ }^{125}$ In the course of reaching this holding, Justice Stevens included a footnote in which he stated that "[a]cademic freedom thrives not only on the independent and uninhibited exchange of ideas among teachers and students, but also, and somewhat inconsistently, on autonomous decisionmaking by the academy itself." 126 Justice Stevens did not expand on his "somewhat inconsistently" language but many have taken his opinion as a quiet yet affirmative nod in favor of Judge Posner's Piarowski doctrine. ${ }^{127}$

\section{b. The Fourth Circuit: Urofsky v. Gilmore}

Finally and most recently, in Urofsky v. Gilmore, ${ }^{128}$ the Fourth Circuit weighed in on the academic freedom debate and the purported tension between institutional and individual academic freedom. ${ }^{129}$ The plaintiffs in this case were professors at public colleges and universities in Virginia who brought suit to challenge the constitutionality of a Virginia statute that prohibited them from accessing sexually explicit material on state computers, for work-related purposes, without prior approval from the university. ${ }^{130}$ The professors argued:

[T]hat a university professor possesses a constitutional right to determine for himself, without the input of the university... the subjects of his research, writing, and teaching. [The professors] maintain[ed] that by requiring professors to obtain university approval before accessing sexually explicit materials on the Internet in connection with their research, the [statute] infringe[d] this individual

123. 474 U.S. 214 (1985)

124. See Hiers, supra note 80 , at 81 .

125. See Ewing, 474 U.S. at 215-16, 221-23, 228.

126. Id. at $226 \mathrm{n} .12$ (citations omitted). See generally Hiers, supra note 80, at 81-82 (quoting and analyzing the same footnote from Ewing).

127. See Hiers, supra note 80, at 81-82 (quoting Ewing, 474 U.S. at 226 n.12).

128. 216 F.3d 401 (4th Cir. 2000) (en banc) (Wilkins, J.)

129. See Hiers, supra note 80, at 95-104 (discussing the Fourth Circuit's decision in Urofsky extensively and highlighting the distinction between individual and institutional academic freedom explored in the Fourth Circuit's opinion). See generally Smith, supra note 54, at 336-60 (discussing the Urofsky case at length while strongly criticizing the Fourth Circuit's opinion but not focusing on the distinction between individual and institutional academic freedom).

130. Urofsky, 216 F.3d at 404-05; see also Smith, supra note 54, at 336-37 (detailing the factual background of the Urofsky case). 
right of academic freedom. ${ }^{131}$

The court, however, disagreed and concluded "that to the extent the Constitution recognizes any right of 'academic freedom' above and beyond the First Amendment rights to which every citizen is entitled, the right inheres in the University, not in individual professors, and is not violated by the terms of the [statute]." ${ }^{\prime 132}$ The court went on to conclude that, while academic freedom has never been expressly defined, the case law that does exist "appears to have recognized only an institutional right of self-governance in academic affairs."

This ruling by the Fourth Circuit remains good law but it has faced heavy criticism from those who have argued that the Fourth Circuit improperly interpreted academic freedom jurisprudence when it declared that the case law supported institutional but not individual academic freedom. ${ }^{134}$ Instead the Supreme Court has focused on individual and institutional academic freedom equally, never clearly distinguishing one above the other. ${ }^{135}$ Proponents of this argument go on to state that the distinction between institutional and individual academic freedom is a false one, noting that "[a] professor's freedom means little if her university is shackled by the whim of the state, and a university's freedom means little if its professors are pawns of the state." ${ }^{\text {"136 }}$ Other critics have argued that, while the distinction between individual and institutional academic freedom is a valid one, the individual component is not as easily swept aside as the Fourth Circuit makes it seem. ${ }^{137}$ Rather the court should have recognized that individual academic freedom qualifies for First Amendment protection given that "the whole justification for academic freedom is that the professional speech of professors does concern the public."138 Regardless of which argument is more compelling, both present strong cases undermining the Fourth

\footnotetext{
131. Urofsky, 216 F.3d at 409-10.

132. Id. at 410 .

133. See id. at 412 .

134. See, e.g., Rebecca Gose Lynch, Comment, Pawns of the State or Priests of Democracy? Analyzing Professors' Academic Freedom Rights Within the State's Managerial Realm, 91 CAL. L. REV. 1061, 1102-07 (2003) (criticizing the Urofsky court because it "unnecessarily distinguished between the institutional and individual rights of academic freedom, and categorically denied the existence of the individual right" and partly blaming this mistake on the court's incorrect interpretation of Supreme Court precedent regarding academic freedom).

135. Id. at 1103

136. Id.

137. See J. Peter Byrne, The Threat to Constitutional Academic Freedom, 31 J.C. \& U.L. 79, 89-91, 112 (2004).

138. Id. at 112
} 
Circuit's ruling in Urofsky and potentially justify why the Fourth Circuit's precedent has been slow to catch on.

\section{ANALYSIS}

This part will analyze the Kansas campus carry statute by asking and answering three important questions. The first section asks: Are university professors and faculty members entitled to an individual right of academic freedom? The answer is almost assuredly yes, based on the historical context of academic freedom as well as the limited but still forceful Supreme Court jurisprudence that pertains to the doctrine. The second section then asks: Assuming that individual academic freedom is a constitutional freedom, what level of scrutiny should courts apply when a government action allegedly infringes upon that freedom? This Comment argues that when it comes to the Kansas campus carry statute, intermediate scrutiny should apply because the law is content-neutral but still has an incidental effect on speech. Finally, the third section asks: Does the Kansas campus carry statute withstand intermediate scrutiny? This Comment argues that it does not because the statute does not further an important government interest and even if it did, its restrictions on speech are more than are necessary to do so. Therefore, based on the analysis of these three questions, this part will conclude that the Kansas campus carry statute impermissibly violates the individual academic freedom of university professors and faculty members and therefore should be struck down.

\section{A. Does Individual Academic Freedom Exist?}

Individual academic freedom is clearly contemplated and encompassed by both the 1915 Declaration and the 1940 statement. ${ }^{139}$ In fact, both the 1915 Declaration and the 1940 statement focus almost exclusively on the academic freedom of individual professors, paying almost no attention to the academic freedom of the institution. ${ }^{140}$ However, as noted above, the 1915 Declaration and 1940 statement are merely professional declarations, both of which lack legal effect unless they are incorporated into official university policies or employment

139. See Comm. on Acad. Freedom \& Acad. Tenure, Am. Ass'n of Univ. Professors, supra note 67; Statement of Principles, 1940, supra note 74.

140. See sources cited supra note 139; see also Smith, supra note 54, at 310-13 (describing both the 1915 Declaration and 1940 statement as focused on individual academic freedom); Spurgeon, supra note 62, at 123-24, $124 \mathrm{n} .90$ (explaining how the focus of the 1915 Declaration was on professors, not students or institutions). 
contracts. ${ }^{141}$ The Supreme Court has weighed in on the issue but its academic freedom jurisprudence is less clear than either of the professional standards, leaving an ambiguity within the law that has yet to be resolved.

In Keyishian v. Board of Regents of the University of New York, ${ }^{142}$ the Supreme Court provided its most clear and complete explanation of academic freedom to date. ${ }^{143}$ There the Court stated that the United States "is deeply committed to safeguarding academic freedom, which is of transcendent value to all [Americans] and not merely to the teachers concerned. That freedom is therefore a special concern of the First Amendment, which does not tolerate laws that cast a pall of orthodoxy over the classroom." 144 By couching academic freedom within the scope of the First Amendment, the Supreme Court was implying that academic freedom should be considered a constitutional freedom. ${ }^{145}$ That freedom was intended "to be enjoyed in the first instance by teachers" largely because of the vital role they play in ensuring the future of American democracy. ${ }^{146}$ The Court emphasized this conclusion by quoting directly from the Sweezy plurality, stating that "[s]cholarship cannot flourish in an atmosphere of suspicion and distrust. Teachers and students must always remain free to inquire, to study and to evaluate, to gain new maturity and understanding; otherwise . . civilization will stagnate and die." 147 However, despite this seemingly clear nod in favor of individual academic freedom, a circuit split has developed over whether the Supreme Court intended to include individual academic freedom as a constitutional freedom within the scope of the First Amendment.

141. See Smith, supra note 54, at 312-13; see also Spurgeon, supra note 62, at 128-29 (stating that the AAUP and its policy documents are not legally enforceable).

142. 385 U.S. 589 (1967).

143. See Hiers, supra note 80 , at 41-43; White, supra note 77, at 810-12.

144. Keyishian, 385 U.S. at 603; see also J. Peter Byrne, supra note 102, at 296-98 (quoting Keyishian, 385 U.S. at 603) (making several observations about the quoted passage from Keyishian); Hiers, supra note 80, at 42-43 (quoting Keyishian, 385 U.S. at 603) (discussing and explaining the importance of the quoted passage from Keyishian); White, supra note 77, at 810-12 (emphasis omitted) (quoting Keyishian, 385 U.S. at 603) (discussing the place of the quoted passage from Keyishian in the context of academic freedom).

145. Hiers, supra note 80 , at 35-36.

146. See id. at $42-43$ (emphasis omitted).

147. Keyishian, 385 U.S. at 603 (quoting Sweezy v. New Hampshire, 354 U.S. 234, 250 (1957) (plurality opinion)); see also Hiers, supra note 80, at 42-43 (quoting Keyishian, 385 U.S. at 603 (quoting Sweezy, 354 U.S. at 250)) (analyzing the language of the paragraph of Sweezy quoted by the Court in Keyishian). 


\section{The Circuit Split}

This split among the circuit courts stems largely from the ambiguous nature of the Supreme Court's academic freedom jurisprudence as well as the relatively unclear dichotomy - between individual and institutional academic freedom - that has emerged as a result. ${ }^{148}$ As noted earlier, the Fourth Circuit's decision in the case of Urofsky v. Gilmore ${ }^{149}$ went "so far as to declare that academic freedom belongs exclusively to institutions, and that faculty are not, and never have been, entitled to academic freedom."150 The Fourth Circuit specifically concluded, "that to the extent the Constitution recognizes any right of 'academic freedom' above and beyond the First Amendment rights to which every citizen is entitled, the right inheres in the University, not in individual professors." 151 In reaching this conclusion, the Urofsky court emphasized that the academic freedom jurisprudence does not create a new First Amendment right for university professors but rather only grants them the limited First Amendment rights enjoyed by all public employees. ${ }^{152}$ Therefore, as the court noted, "[t] he Supreme Court, to the extent it has constitutionalized a right of academic freedom at all, appears to have recognized only an institutional right."153

By contrast, the Seventh Circuit's decision in Piarowski v. Illinois Community College District $515,^{154}$ stated that the term "academic freedom" was "equivocal." 155 Drawing on the Supreme Court's language in Sweezy, Judge Posner characterized academic freedom as both the freedom of the institution as well as the freedom of the individual teacher and then posited that each is in conflict with the other. ${ }^{156}$ The Supreme Court lent some credence to this interpretation, albeit in a footnote that

\footnotetext{
148. See generally Hiers, supra note 80 , at 64-109.

149. 216 F.3d 401 (4th Cir. 2000) (en banc).

150. Hiers, supra note 80, at 36; see also Gose Lynch, supra note 134, at 1102, 1107; White, supra note 77, at 833-34; supra also Section II.B.2.b.

151. Urofsky, 216 F.3d at 410.

152. See id. at 410-15; see also Hiers, supra note 80 , at 36 ("[Urofsky] suggests that college and university faculty are entitled only to the same limited First Amendment speech protections enjoyed by public employees in other contexts ....").

153. Urofsky, 216 F.3d at 412.

154. 759 F.2d 625 (7th Cir. 1985).

155. Id. at 629; see also Hiers, supra note 80, at 78-81 (quoting Piarowski, 759 F.2d at 629).

156. Piarowski, 759 F.2d at 629; see also Hiers, supra note 80, at 78 ("“Piarowski] included language to the effect that academic freedom is an 'equivocal' term because it refers both to institutional academic freedom and individual academic freedom, and that these two freedoms conflict with each other." (quoting Piarowski, 759 F.2d at 629)).
} 
was merely dicta, in Regents of University of Michigan v. Ewing ${ }^{157}$ where Justice Stevens acknowledged that "[a]cademic freedom thrives not only on the independent and uninhibited exchange of ideas among teachers and students, but also, and somewhat inconsistently, on autonomous decisionmaking by the [institution] itself." 158 Justice Stevens did not specifically cite to Judge Posner's decision in Piarowski (though the Supreme Court had denied certiorari to that case just ten days prior ${ }^{159}$ ), nor did he expand on what he meant by his "somewhat inconsistently" language. ${ }^{160}$ But despite this, many commentators have pointed to the Ewing footnote as the Supreme Court's implicit recognition of individual academic freedom as a valid constitutional freedom within the scope of the First Amendment. ${ }^{161}$

\section{Resolving the Conflict}

The American academic freedom jurisprudence is necessarily couched in the historical context that the doctrine grew up in. Therefore, that historical context must be considered when resolving questions about the scope of the doctrine, including the split between the Fourth and Seventh Circuits over whether individual academic freedom should be included as a constitutional freedom within the purview of the First Amendment. Ultimately the Seventh Circuit's acknowledgement that individual academic freedom is valid and within the scope of the First Amendment is more in line with this historical context and therefore finds more support in the case law. As a result, individual academic freedom should be recognized as, at the very least, equal to institutional academic freedom and therefore protected as a "special concern of the First Amendment."162

Beginning with the German tradition, there is a clear emphasis

157. 474 U.S. 214 (1985).

158. Id. at $226 \mathrm{n} .12$ (1985) (citations omitted); see also Hiers, supra note 80, at 81-82 (quoting Ewing, 474 U.S. at 226 n.12) (discussing Justice Stevens' footnote in Ewing and describing it as dicta).

159. Hiers, supra note 80 , at 81 .

160. Id. at 82 .

161. See, e.g., Nancy J. Whitmore, First Amendment Showdown: Intellectual Diversity Mandates and the Academic Marketplace, 13 COMM. L. \& POL'Y 321, 356, 356 n.270 (2008); see also White, supra note 77, at 824 (explaining that Ewing is "characterized by some scholars as the high water mark for academic freedom as an individual right possessed by individual members of the faculty").

162. See Keyishian v. Bd. of Regents of the Univ. of N.Y., 385 U.S. 589, 603 (1967) (stating that academic freedom is "a special concern of the First Amendment" but not explicitly stating that individual academic freedom specifically is such a concern). 
placed on the academic freedom of the individual. Two of the three principles - Lehrfreiheit and Lernfreiheit-focused almost exclusively on individual academic freedom. ${ }^{163}$ The former, Lehrfreiheit, emphasized the freedom of individual professors and faculty members and granted them the right to teach their discipline in the manner of their choosing and to control the learning environment of their classrooms, all without fear of state or church retribution. ${ }^{164}$ The latter, Lernfreiheit, while not as relevant as Lehrfreiheit to the topic of this Comment, also emphasized the academic freedom of an individual. ${ }^{165}$ Specifically, Lernfreiheit referred to the freedom of a student to study the topic of his or her choosing without being subjected to university direction, save for those courses that were required to prepare students for professional examinations or licenses. ${ }^{166}$ Given that these German principles heavily influenced the development of the American academic freedom doctrine, ${ }^{167}$ it is telling that they put such an emphasis on the rights of the individual.

As the concept of academic freedom migrated to the United States, it brought many of its German influences and characteristics along with it. ${ }^{168}$ Based on those German influences and characteristics, the AAUP issued its 1915 Declaration, ${ }^{169}$ the first conception of academic freedom in the United States. ${ }^{170}$ The 1915 Declaration emphasized three main elements: "[1] freedom of inquiry and research; [2] freedom of teaching within the university or college; and [3] freedom of extra-mural utterance and action." individual academic freedom of professors. ${ }^{172}$ In fact, while the 1915 Declaration discusses the role that academic institutions play and describes, at length, their overarching function, it does not include any provision proposing any kind of institutional academic freedom. ${ }^{173}$

\footnotetext{
163. See Metzger, supra note 55, at 1269-70.

164. Seeid.

165. See id. at 1270.

166. See id.

167. See Smith, supra note 54, at 309.

168. See id.

169. Comm. on Acad. Freedom \& Acad. Tenure, Am. Ass'n of Univ. Professors, supra note 67.

170. See Metzger, supra note 55, at 1267; Smith, supra note 54, at 310;

171. Comm. on Acad. Freedom \& Acad. Tenure, Am. Ass'n of Univ. Professors, supra note 67, at 20 .

172. See id. ("It need scarcely be pointed out that the freedom which is the subject of this report is that of the teacher. Academic freedom in this sense comprises three elements: freedom of inquiry and research; freedom of teaching within the university or college; and freedom of extra-mural utterance and action.").

173. See id. at 20-42; see also Smith, supra note 54, at 311 ("[T]
} 
Given that the AAUP is a professional organization representing college professors, this largely makes sense. The AAUP re-emphasized its 1915 Declaration with its 1940 statement that, again, focused almost exclusively on the individual academic freedom of university faculty and professors. ${ }^{174}$ Therefore, particularly when combined with the German tradition, the historical background and context surrounding the American conception of academic freedom weighs heavily in favor of including individual academic freedom in the modern day definition of the doctrine. ${ }^{175}$

It was against this historical backdrop that the Supreme Court based most, if not all, of its academic freedom jurisprudence. Though many commentators have often lamented the ambiguous nature and lack of clarity that accompanies the Supreme Court's academic freedom decisions, ${ }^{176}$ the Court's language, particularly in the context of the historical precedent, leans strongly in favor of individual academic freedom. Specifically, in Keyishian the Supreme Court characterized academic freedom as "a special concern of the First Amendment, which does not tolerate laws that cast a pall of orthodoxy over the classroom." "177 This language lends credence to the idea that academic freedom should be included among the constitutional freedoms and therefore afforded all of the protections that those freedoms inherently entail. $^{178}$

What this oft-quoted passage does not do, however, is clearly state who is entitled to assert that freedom: just the academic institutions or the individual faculty and professors as well? The Court fails to directly answer this question, which results in the above-mentioned circuit split

individual professor rather than the university in its institutional capacity."); Spurgeon, supra note 62, at 124 n.90 (explaining that the 1915 Declaration did not concern itself with institutional academic freedom).

174. See Statement of Principles, 1940, supra note 74; see also Smith, supra note 54, at 312 ("[T] 1940 Statement treated academic freedom as the individual freedom of university professors.").

175. See Smith, supra note 54, at 309 ("[T]he American definition of academic freedom was more focused than its German precursor in that the American theory centered almost exclusively on the freedom of the individual teacher and researcher.").

176. See, e.g., Byrne, supra note 102, at 252-53; Smith, supra note 54, at 324-25; Spurgeon, supra note 62 , at 141; White, supra note 77 , at $812-13,841-42$.

177. Keyishian v. Bd. of Regents of the Univ. of N.Y., 385 U.S. 589, 603 (1967); see also Byrne, supra note 102, at 296-98 (quoting Keyishian, 385 U.S. at 603) (highlighting a few aspects of the quoted passage from Keyishian); Hiers, supra note 80, at $42-43$ (quoting Keyishian, 385 U.S. at 603) (examining the quoted passage from Keyishian and explaining its importance); White, supra note 77, at 810-12 (emphasis omitted) (quoting Keyishian, 385 U.S. at 603) (placing the quoted passage from Keyishian in the broader context of academic freedom).

178. See supra notes $98-103$ and accompanying text. 
between the Fourth and Seventh Circuits. ${ }^{179}$ But what the Court does do is follow its seminal statement on academic freedom with a quote from its earlier plurality decision in Sweezy v. New Hampshire ${ }^{180}$ :

The essentiality of freedom in the community of American universities is almost self-evident. No one should underestimate the vital role in a democracy that is played by those who guide and train our youth. To impose any strait jacket upon the intellectual leaders in our colleges and universities would imperil the future of our Nation. No field of education is so thoroughly comprehended by man that new discoveries cannot yet be made. Particularly is that true in the social sciences, where few, if any, principles are accepted as absolutes. Scholarship cannot flourish in an atmosphere of suspicion and distrust. Teachers and students must always remain free to inquire, to study and to evaluate, to gain new maturity and understanding; otherwise our civilization will stagnate and die.

By including the Sweezy plurality quotation in its holding, the Keyishian Court made that language a part of its academic freedom precedent. ${ }^{182}$ This is significant because the Sweezy quote specifically mentions teachers, and others involved with educating American youth, as vital components of a vibrant democracy. ${ }^{183}$ They must therefore "always remain free to inquire, to study and to evaluate, to gain new maturity and understanding; otherwise... civilization will stagnate and die."184 Ultimately, this language makes clear that individual academic freedom is and should be included as a constitutional freedom within the purview of the First Amendment. ${ }^{185}$ And when put into the historical context that has surrounded academic freedom since its inception, the conclusion that individual faculty members and professors are entitled to their own,

179. See discussion supra Section III.A.1.

180. 354 U.S. 234 (1957).

181. Keyishian, 385 U.S. at 603 (quoting Sweezy, 354 U.S. at 250); see also Hiers, supra note 80, at 42-43 (quoting Keyishian, 385 U.S. at 603 (quoting Sweezy, 354 U.S. at 250)) (analyzing the above language from Sweezy quoted in Keyishian and concluding that the Keyishian opinion in general demonstrates the high value placed by the Court on the academic freedom of teachers).

182. See Hiers, supra note 80 , at 43 ("By virtue of its quotation with obvious approval by the Keyishian majority, this language from the Sweezy plurality became the language of the Supreme Court.").

183. See Sweezy, 354 U.S. at 250; see also Hiers, supra note 80, at 40, 42-43; Smith, supra note 54, at 318-19 ("The passionate language in [Sweezy] extols the virtues of academic freedom by recognizing the importance to society of individual scholarship.").

184. Sweezy, 354 U.S. at 250; see also Hiers, supra note 80, at 40, 44-45 (quoting Sweezy, 354 U.S. at 250) (analyzing the relevant language from Sweezy and focusing on the decision's focus on protecting the academic freedom of professors); Smith, supra note 54, at 318-19 (quoting Sweezy, 354 U.S. at 250) (discussing the passage from Sweezy and concluding that the Court's decision is about "the importance to society of individual scholarship.").

185. See Hiers, supra note 80 , at 40-45; Smith, supra note 54, at 318-21. 
individual right of academic freedom is nearly unassailable.

\section{B. If Individual Academic Freedom Exists, What Level of Scrutiny Should the Courts Apply?}

Having established that individual academic freedom is almost certainly included as a constitutional freedom within the scope of the First Amendment, the question then becomes: What level of scrutiny should a court apply to laws and regulations that are alleged to have infringed upon that freedom? To "reconcile individual liberties with societal needs," courts utilize so-called levels, or tiers, of scrutiny. ${ }^{186}$ "These tiers were created by the Supreme Court to formalize the jurisprudence of rights, and reconcile the general presumption of constitutionality and deference to legislative bodies with the inherently countermajoritarian nature of judicial review." 187 The baseline of these levels of scrutiny is rational basis review, a "highly deferential" level of scrutiny that only requires that the statute be "rationally related to a legitimate state interest." 188 However, "[a]lthough rational basis review provide[s] an acceptable starting point for analysis in most cases," in reality it plays an "extremely limited role" when it comes to decisions involving free speech. ${ }^{189}$ As a result, courts are left with strict and intermediate scrutiny for evaluating free speech claims. ${ }^{190}$

\section{Strict Scrutiny}

Strict Scrutiny constitutes the most exacting test that a court can apply to an infringing statute. To satisfy strict scrutiny analysis, a law must have been passed to further a "compelling governmental interest; must be narrowly tailored to achieve that interest; and, must be the least restrictive means of advancing that interest." 191 This is an incredibly high standard to meet, so high in fact that many consider it to be a test that is "fatal in fact," resulting in per se findings that statutes are unconstitutional. $^{192}$ When it comes to free speech, the Supreme Court

\footnotetext{
186. Ashutosh Bhagwat, The Test That Ate Everything: Intermediate Scrutiny in First Amendment Jurisprudence, 2007 U. ILL. L. REV. 783, 784.

187. Id.

188. See, e.g., City of New Orleans v. Dukes, 427 U.S. 297, 303 (1976); Bhagwat, supra note 186 , at 784,786 (quoting Dukes, 427 U.S. at 303).

189. See Bhagwat, supra note 186 , at 786-87.

190. See id. at 784, 786-88.

191. 16A AM. JUR. 2D Constitutional Law $\$ 480$ (2017).

192. See Bhagwat, supra note 186, at 784 (quoting Gerald Gunther, Foreword: In Search of
} 
has held that strict scrutiny applies when a statute imposes content-based restrictions on speech. ${ }^{193}$ "As a general rule, laws that by their terms distinguish favored speech from disfavored speech on the basis of the ideas or views expressed are content based."194 Similarly, laws that "restrict expression because of its message, its ideas, its subject matter, or its content" are also disfavored and subjected to strict scrutiny analysis by the courts. ${ }^{195}$ Examples of state action that has failed to satisfy the courts' exacting strict scrutiny analysis include regulations that limit programming on sexually explicit channels to certain hours ${ }^{196}$ and police regulations that only permit schools to be picketed when the picketing pertains to labor disputes but does not permit picketing at schools for other reasons. ${ }^{197}$ And in terms of individual academic freedom, a statute that seeks to mandate what can or cannot be taught in college classrooms would likely be subject to strict scrutiny analysis.

The Kansas campus carry statute is almost certainly not subject to strict scrutiny analysis because it is, facially, a content-neutral statute. Section $75-7 \mathrm{c} 20$ does not try to regulate any specific type of speech or form of expression by mandating that concealed carry may only be prohibited in classrooms that teach certain subjects (i.e. concealed carry firearms may be prohibited in calculus classes but not in English classes) or in classes taught by teachers who possess certain political beliefs (i.e. conservative professors may prohibit concealed carry firearms in their classrooms but liberal professors may not). ${ }^{198}$ Nor does section $75-7 \mathrm{c} 20$ seek to make arbitrary distinctions between different types of speech. ${ }^{199}$ Instead, the statute uses an objective standard (i.e. public buildings that

Evolving Doctrine on a Changing Court: A Model for a Newer Equal Protection, 86 HARV. L. ReV. $1,8(1972)$ ).

193. See, e.g., Turner Broad. Sys., Inc. v. FCC, 512 U.S. 622, 642 (1994) (first citing Simon \& Schuster, Inc. v. Members of the N.Y. State Crime Victims Bd., 502 U.S. 105, 115 (1991); then citing Simon \& Schuster, 502 U.S. at 125-26 (Kennedy, J., concurring in the judgment); and then citing Perry Educ. Ass'n v. Perry Local Educators' Ass'n, 460 U.S. 37, 45 (1983)); 16A AM. JUR. 2D Constitutional Law $\S 480$ (2017); Bhagwat, supra note 186, at 787.

194. Turner, 512 U.S. at 643 (first citing Burson v. Freeman, 504 U.S. 191, 197 (1992); and then citing Boos v. Barry, 485 U.S. 312, 318-19 (1988) (plurality opinion)).

195. See Police Dep't of Chi. v. Mosley, 408 U.S. 92, 95 (1972) (first citing Cohen v. California, 403 U.S. 15, 24 (1971); then citing Street v. New York, 394 U.S. 576 (1969); then citing N.Y. Times Co. v. Sullivan, 376 U.S. 254, 269-70 (1964); then citing NAACP v. Button, 371 U.S. 415, 445 (1963); then citing Wood v. Georgia, 370 U.S. 375, 388-89 (1962); then citing Terminiello v. City of Chicago, 337 U.S. 1, 4 (1949); and then citing De Jonge v. Oregon, 299 U.S. 353, 365 (1937)).

196. See United States v. Playboy Entm’t Grp., Inc., 529 U.S. 803, 806-07, 826-27 (2000).

197. See Mosley, 408 U.S. at 94-99.

198. See KAn. Stat. AnN. § 75-7c20 (Supp. 2016).

199. See id. 
have adequate security measures) to determine where concealed carry may be prohibited and where it must be allowed. ${ }^{200}$ In fact, section 75$7 \mathrm{c} 20$ makes absolutely no mention of free speech, nor in any other way implicates the rights protected by the First Amendment. ${ }^{201}$ Instead, the statute's language is almost entirely focused on implementing the new policy. This includes provisions detailing where concealed carry can and cannot be prohibited, language about the authority of judges and corrections officers to limit the scope of the new policy, and instructions for building and campus administrators on how to apply for and obtain the four-year exemption from the policy that is set to expire on July 1, 2017. ${ }^{202}$ To apply strict scrutiny analysis to the Kansas campus carry statute would therefore be too high of a burden to place on a law that does not directly infringe upon the individual academic freedom of Kansas professors.

\section{Intermediate Scrutiny}

Intermediate scrutiny was developed by the Supreme Court as a combination of "the highly deferential rational basis review and the almost always "fatal in fact' strict scrutiny" analysis. ${ }^{203}$ This was largely because, "[w]hatever the merits of the two-tiered paradigm in due process and equal protection analysis, in the area of free speech it was never adequate to explain the subtleties of the Court's jurisprudence."204 To satisfy intermediate scrutiny analysis, a challenged statute must further an important government interest that is not related to suppressing free expression and the restriction must be "no greater than is essential to the furtherance of that interest." 205

When it comes to free speech, the Supreme Court has held that intermediate scrutiny applies to statutes that are content-neutral and yet

\footnotetext{
200. See id.

201. See id.

202. See id.

203. See Bhagwat, supra note 186, at 784-85 (footnote omitted) (quoting Gunther, supra note 192, at 8). The two-tiered paradigm, which had worked well for Due Process and Equal Protection analysis, failed to effectively handle the subtleties of the the Court's First Amendment Jurisprudence. $I d$. at 784 . This led to a period of judicial chaos, during which time courts developed a number of tests, each designed to deal with a unique component of free speech law. Id. "However, in the early to mid-1980s, the Supreme Court, and even more so the lower courts, began to bring order to this tangle, ultimately combining these various 'tests' into a single, unitary standard of review that has come to be called intermediate scrutiny." Id.

204. Id. at 784 .

205. See 16A Am. Jur. 2D Constitutional Law $§ 480$ (2017).
} 
are still alleged to infringe upon free speech. ${ }^{206}$

The principal inquiry in determining content neutrality, in speech cases generally and in time, place, or manner cases in particular, is whether the government has adopted a regulation of speech because of disagreement with the message it conveys. The government's purpose is the controlling consideration. A regulation that serves purposes unrelated to the content of expression is deemed neutral, even if it has an incidental effect on some speakers or messages but not others. ${ }^{207}$

The Court chose to make this distinction largely because it reasoned that content-neutral regulations posed "a less substantial risk of excising certain ideas or viewpoints from the public dialogue."208 In other words, if the express purpose of the government action was not to compel or prohibit speech, then courts were more inclined to be deferential in accommodating the government's interest. ${ }^{209}$ For this reason, the Court has applied intermediate scrutiny to a statute requiring cable providers to carry certain programming ${ }^{210}$ and municipal noise regulations designed to ensure that music performances did not disturb local residents ${ }^{211}$ and, in both instances, allowed the regulations to stand. ${ }^{212}$

In the context of academic freedom, statutes with the stated purpose of promoting student and faculty safety but that also have incidental effects on the individual academic freedom (i.e. the speech) of professors would likely be subject to this level of scrutiny. As a result, it is arguable that the Kansas campus carry statute would have to withstand intermediate scrutiny to remain viable if it were to be challenged on individual academic freedom grounds. This is largely because, as noted above, section 75-7c20 is inarguably content-neutral in its approach as well as in its application. ${ }^{213}$ It does not include any provision favoring or disfavoring any particular subjects or topics, nor does it grant special privileges or more severe restrictions based on the subject matter of the courses being taught. ${ }^{214}$ And yet, despite this neutrality, it cannot be

\footnotetext{
206. See, e.g., Ward v. Rock Against Racism, 491 U.S. 781, 791 (1989) (first citing Clark v. Cmty. for Creative Non-Violence, 468 U.S. 288, 293 (1984); and then citing Heffron v. Int'l Soc'y for Krishna Consciousness, Inc., 452 U.S. 640, 648 (1981)).

207. Id. (citation omitted) (first citing Clark v. Cmty. for Creative Non-Violence, 468 U.S. 288, 295 (1984); and then citing City of Renton v. Playtime Theatres, Inc., 475 U.S. 41, 47-48 (1986)).

208. See Turner Broad. Sys., Inc. v. FCC, 512 U.S. 622, 642 (1994).

209. See id.

210. See id. at 662-68.

211. See Ward v. Rock Against Racism, 491 U.S. 781, 803 (1989).

212. See cases cited supra notes $210-11$.

213. See Kan. Stat. AnN. § 75-7c20 (Supp. 2016); see also supra Section III.B.1.

214. See § 75-7c20; see also discussion supra Section III.B.1.
} 
ignored that section 75-7c20 will, in all likelihood, have an incidental and chilling effect on the topics professors are willing to cover in their classrooms, the types of discussions professors are willing to facilitate among their students, and the type of environment professors choose to create within their classes. ${ }^{215}$ In other words, section $75-7 \mathrm{c} 20$ almost certainly infringes, albeit incidentally, on the academic freedom of individual professors and faculty members. As a result, if the law were to be challenged on individual academic freedom grounds, it would have to withstand intermediate scrutiny in order to remain viable.

\section{Does the Kansas Campus Carry Statute Survive Intermediate Scrutiny?}

As noted above, the test that must be satisfied to withstand intermediate scrutiny analysis first requires content-neutral statutes that nevertheless incidentally restrict speech to further an important governmental interest that is not related to the suppression of that free expression. ${ }^{216}$ Second, the incidental restriction on speech must be "no greater than is essential to the furtherance of that" important governmental interest. ${ }^{217}$

1. Further an Important Governmental Interest Not Related to Suppressing Free Expression

For the Kansas campus carry statute to withstand heightened scrutiny, the government must first demonstrate that it furthers an important governmental interest that is unrelated to the suppression of

\footnotetext{
215. See Kent Anderson, Dare I Say This? - The Chilling Effect of Gun Laws on Academic $\begin{array}{lllll}\text { Free Speech, SCHOLARLY KitCHEN } & \text { (Nov. }\end{array}$ https://scholarlykitchen.sspnet.org/2014/11/05/dare-i-say-this-the-chilling-effect-of-gun-laws-onacademic-free-speech/; Ian Bogost, The Armed Campus in the Anxiety Age, ATLANTIC (Mar. 9, 2016), https://www.theatlantic.com/education/archive/2016/03/campus-carry-anxiety-age/472920/; Firmin Debrabander, How Guns Could Censor College Classrooms, ATLANTIC (Mar. 4, 2016), https://www.theatlantic.com/education/archive/2016/03/the-steep-cost-of-allowing-guns-in-thecollege-classroom/472296/; Katie Reilly, How Guns on Campus Could Change What Texas Teaches, TIME (Feb. 26, 2016, 2:18 PM), http://time.com/4237638/campus-carry-texas-universities/; Benjamin Wermund, UH Faculty Suggest Steering Clear of Some Topics if Students Armed, CHRON (Feb. 24, 2016, 8:30 AM), http://www.chron.com/local/education/campus-chronicles/article/UHfaculty-may-drop-topics-from-curriculum-as-6849002.php. While it is true that many of these concerns are based on fears for the future rather than concrete (and inherently retrospective) data or survey results, the fact is that the campus carry movement is so new, so that type of data simply does not yet exist.

216. See 16A AM. JUR. 2D Constitutional Law $\$ 480$ (2017).

217. Seeid.
} 
free expression. ${ }^{218}$ To this end, the State would likely posit that the Kansas campus carry statute furthers the safety of its citizens by enabling them to defend themselves against armed assailants on public college and university campuses. ${ }^{219}$ However, while safety is an important governmental interest and is clearly not related to the suppression of free expression; in reality, allowing concealed carry firearms on campuses would likely do little to further that governmental interest (i.e. make those campuses safer) and may, arguably, have the exact opposite effect. The statistics from the FBI suggest that carrying a firearm has, at most, a negligible effect at deterring crime and making citizens safer. ${ }^{220}$ In fact, empirical studies go even further and have discovered a correlation between guns and accidental shootings/suicides, suggesting that the more guns present in a society, the more suicides and accidental shootings that occur. ${ }^{221}$ Therefore, while the safety of citizens is an important governmental interest, the Kansas campus carry statute likely does not do anything to further that interest and may even prove detrimental, particularly when it comes to college campuses.

As noted above, universities, such as the University of Kansas, are made up of a unique conglomeration of people who come together from a wide variety of cultures and backgrounds and who carry with them a wide variety of beliefs. ${ }^{222}$ Part of the purpose of college is to expose students to those different cultures and backgrounds in a manner that forces them to constantly challenge each other's beliefs, deal with uncomfortable political and social issues, and re-evaluate how they see the world. At best this results in a campus full of thinkers and innovators who are able to appreciate and see the world from various perspectives. But in getting to that point there are often hurdles that must be overcome,

\footnotetext{
218. See id.

219. See Zeff, supra note 47; Rothschild, supra note 10.

220. See Violence Policy Ctr., Firearm Justifiable Homicides and Non-Fatal Self-

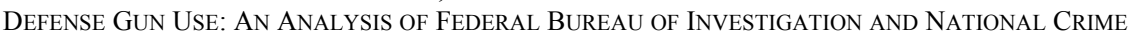
ViCTIMIZATION SURVEY DATA 7 (2015), http://www.vpc.org/studies/justifiable15.pdf/ ("The idea that firearms are frequently used in self-defense is the primary argument that the gun lobby and firearms industry use to expand the carrying of firearms into an ever-increasing number of public spaces and even to prevent the regulation of military-style semiautomatic assault weapons and highcapacity ammunition magazines. Yet this argument is hollow and the assertions false. When analyzing the most reliable data available, what is most striking is that in a nation of more than 300 million guns, how rarely firearms are used in self-defense.").

221. See Harvard Injury Control Research Center: Accidents, Harv. T.H. Chan Sch. PuB. HEALTH, https://www.hsph.harvard.edu/hicrc/firearms-research/gun-threats-and-self-defense-gunuse/ (last visited May 11, 2017); Harvard Injury Control Research Center: Suicide, HARV. T.H. Chan Sch. PuB. HeAlth, https://www.hsph.harvard.edu/hicrc/firearms-research/gun-ownershipand-use/ (last visited Apr. 16, 2017).

222. See supra Part I.
} 
emotions that must be dealt with, and discomfort that must be worked through. It is therefore arguable, and even likely, that introducing concealed carry firearms into this already volatile environment will make it feel less safe and result in the loss of the free exchange of ideas that universities have prided themselves on for centuries. ${ }^{223}$

\section{No More than the Essential Restrictions Necessary to Further That Interest}

Even if the Kansas campus carry statute does further the government's important interest in protecting its citizens, it still very likely fails under intermediate scrutiny because its restrictions go beyond that which are necessary to bring about that protection. This is largely due to the dubiousness of the premise that armed students and faculty make a campus safer, ${ }^{224}$ as well as the existence of more reasonable alternative means for achieving the same goal. As noted previously, it is very unlikely that adding more guns to a university setting will make it safer, particularly since most students and faculty lack training in how to properly respond to an active shooter situation. ${ }^{225}$ And yet, despite this shortcoming, the Kansas legislature chose campus carry as its preferred vehicle for improving campus safety. The effect of that choice is a very real restriction on the academic freedom of professors because, for many, it limits the subjects they are willing to teach as well as the types of discussions they are willing to facilitate among their students. ${ }^{226}$ In particular, it dissuades professors from lecturing on important but controversial topics or taking positions that might be met with angry and,

223. See Shaundra K. Lewis \& Daniel Alejandro De Luna, Symposium on "Texas Gun Law and the Future": The Fatal Flaws in Texas's Campus Carry Law, 41 T. MARSHALl L. ReV. 135, 138-40 (2016). The authors specifically note that the Texas campus carry statute has already had an appreciable impact on subjects professors are willing to teach, how accessible professors are willing to make themselves to students, and has limited the ways in which professors feel they can have an impact with their students. Id. at 138-39. Some professors have reportedly even left the state to take up teaching positions in less volatile environments. $I d$. at 139. Ultimately, the authors conclude that "[i]n sum, [the campus carry statute] negatively impacts the quality of higher education students will receive, which ... violates the First Amendment of the U.S. Constitution." Id. at 140. This conclusion-which was made in the context of the Texas campus carry statute-is equally applicable to the Kansas campus carry statute.

224. See sources cited supra notes 220-21.

225. See Rebekah Elliott, Note, The Real School Safety Debate: Why Legislative Responses Should Focus on Schools and Not on Guns, 57 ARIZ. L. REV. 523, 549 (2015) ("An investigation conducted by $\mathrm{ABC}$ News concluded that average individuals are not prepared to handle a gun in emergency situations" because "the intensity involved in an active-shooter situation is much more than an average individual can handle ....").

226. See sources cited supra note 215 . 
under the Kansas campus carry statute, potentially armed resistance. ${ }^{227}$ When the alternatives are considered, it is clear that these restrictions go beyond what is necessary to further the government's interest in improving campus safety.

One such alternative is investing in campus law enforcement and putting more officers who are trained and prepared to handle active shooter situations on campuses. ${ }^{228}$ There is little doubt that this would further the state's interest and in a way that has little to no effect on the subject matter professors are willing to teach or the learning environment they wish to create. $^{229}$ Other alternatives include investing in mental health care ${ }^{230}$ and education about non-violent dispute resolution, both of which would effectuate the goal of campus safety without restricting the individual academic freedom of professors. ${ }^{231}$ The Kansas campus carry statute is therefore more restrictive than is necessary to further the state's interest in promoting campus safety by enabling students and faculty members to defend themselves. This means that section $75-7 \mathrm{c} 20$ must ultimately fail under intermediate scrutiny analysis.

\section{CONCLUSION}

Beginning with the great German universities of the 19th Century, the doctrine of academic freedom has sought to protect the academic integrity and free-exchange of ideas that is central to the concept of higher education. ${ }^{232}$ Early in the 20th Century, that doctrine migrated to the United States where it first manifested within professional standards that were produced by labor organizations representing university

227. See sources cited supra note 215 .

228. See Brandi Hephner LeBanc, Kerry Brian Melear \& Brian O. Hemphill, The Debate Over Campus-Based Gun Control Legislation, 40 J.C. \& U.L. 397, 412-14 (2014) (noting the key role that campus law enforcement can and should play in both responding to crises on campus as well as working to prevent them).

229. It is of course conceivable that some professors may object to the presence of a greater law enforcement presence on campus, particularly if they are teaching on topics that some law enforcement personnel find objectionable (e.g. social justice topics). However, this potential incidental restriction is much narrower than the incidental restriction on all controversial topics that the Kansas campus carry statute likely entails.

230. See Tessa Heller, Note, Mandatory School-Based Mental Health Services and the Prevention of School Violence, 24 HEALTH MATRIX 279, 282-83, 315 (2014) (arguing that diagnosing and treating mental illnesses earlier in children can help them "better cope with mental health problems for the rest of their lives").

231. See LeBanc, Melear \& Hemphill, supra note 228, at 413 ("A recent study found that in 33 percent of the active shooter events, the shooter was stopped by the non-violent intervention of a potential victim.").

232. See discussion supra Section II.B.1.a. 
professors and faculty members. ${ }^{233}$ Both of these historical conceptions of academic freedom - the German tradition and the subsequent professional standards - placed a clear emphasis on the protection of the rights of individual professors to teach and exchange ideas freely and without fear of negative repercussions. ${ }^{234}$ However, unless those standards were incorporated into university policy or employment contracts, they largely lacked any type of real legal effect. ${ }^{235}$ That began to change in the 1950s and continued through the 1970s as the Supreme Court took up the issue. ${ }^{236}$ What resulted was a somewhat tenuous acceptance of academic freedom in which the Court acknowledged that academic freedom was essential to the furtherance and future of democracy and, as a result, was a special concern of the First Amendment. ${ }^{237}$ Unfortunately, the Court has yet to clarify what it meant with this ambiguous embrace of academic freedom doctrine, but given the historical background and context that surrounded the Court's decisions, it seems clear that individual academic freedom is included as a constitutional freedom within the scope of the First Amendment. ${ }^{238}$

Because individual academic freedom is a valid constitutional freedom within the purview of the First Amendment, any statutes or government actions that infringe upon that right must withstand the appropriate level of scrutiny, as determined by the Court's First Amendment jurisprudence. ${ }^{239}$ This includes the Kansas campus carry statute that was passed and implemented in 2013, and that will require all public universities within the state of Kansas to allow the concealed carry of firearms beginning on July $1,2017 .{ }^{240}$ If a court were to deem the Kansas campus carry statute to be a content-based regulation, then it would be subject to strict scrutiny and could only be upheld if it is shown to further a compelling government interest by means that are narrowly tailored to that interest and that are the least restrictive means of doing so. ${ }^{241}$ This is an incredibly exacting test, but the Kansas campus carry statute would likely not be held to that high of a standard. ${ }^{242}$ This is largely because the Kansas campus carry statute is almost certainly a

\footnotetext{
233. See discussion supra Section II.B.1.b.i.

234. See discussion supra Section II.B.1.

235. See discussion supra Section II.B.1.b.i.

236. See discussion supra Section II.B.1.b.ii.

237. See discussion supra Section II.B.1.b.ii.

238. See discussion supra Section III.A.

239. See discussion supra Section III.B.

240. See discussion supra Section II.A.2.

241. See discussion supra Section III.B.1.

242. See discussion supra Section III.B.1.
} 
content-neutral statute. ${ }^{243}$ Content-neutral statutes are facially indifferent to the content of speech and most, including the Kansas campus carry statute, make no mention of speech in their provisions. ${ }^{244}$

When content-neutral laws infringe upon a First Amendment right, such as the individual academic freedom of professors, they are still subject to a heightened level of scrutiny, but not to the essentially fatalin-fact strict scrutiny analysis. ${ }^{245}$ This middle ground test is known as intermediate scrutiny and requires the infringing statute to further an important governmental interest that is not related to suppressing speech by means that only restrict a person's rights to the extent necessary to further that interest. ${ }^{246}$

Ultimately, the Kansas campus carry statute must fail, even under the intermediate scrutiny analysis, because it does not further an important governmental interest and, even if it did, it does so in a manner that is far more restrictive than necessary. ${ }^{247}$ The government's central interest in enacting the statute was to promote the safety of its citizens by allowing them to better defend themselves against armed assailants in buildings on college and university campuses. ${ }^{248}$ However, empirical evidence suggests that allowing firearms on campus will actually have the opposite effect mostly due to the increase in accidents and suicides that are associated with an increase in guns. ${ }^{249}$ In addition, even if it did make campuses safer, the Kansas campus carry statute is far too restrictive to be allowed to stand under intermediate scrutiny. ${ }^{250}$ This is particularly true when looking at alternatives - such as investing in law enforcement on campus, mental health care, and education in non-violent conflict resolution - all of which improve campus safety with little to no restrictions on the academic freedom of individual professors. ${ }^{251}$ As a result, the Kansas campus carry statute likely fails intermediate scrutiny analysis and should be set aside because it unacceptably infringes on the individual academic freedom of professors and faculty members at public colleges and universities throughout the state.

\footnotetext{
243. See discussion supra Section III.B.2.

244. See discussion supra Section III.B.2.

245. See discussion supra Section III.B.2.

246. See discussion supra Section III.B.2.

247. See discussion supra Section III.C.

248. See discussion supra Section III.C.

249. See discussion supra Section III.C.

250. See discussion supra Section III.C.

251. See discussion supra Section III.C.
} 